ENTREPRENEURSHIP AND SUSTAINABILITY ISSUES

ISSN 2345-0282 (online) http://jssidoi.org/jesi/

2020 Volume 7 Number 3 (March)

http://doi.org/10.9770/jesi.2020.7.3(14)
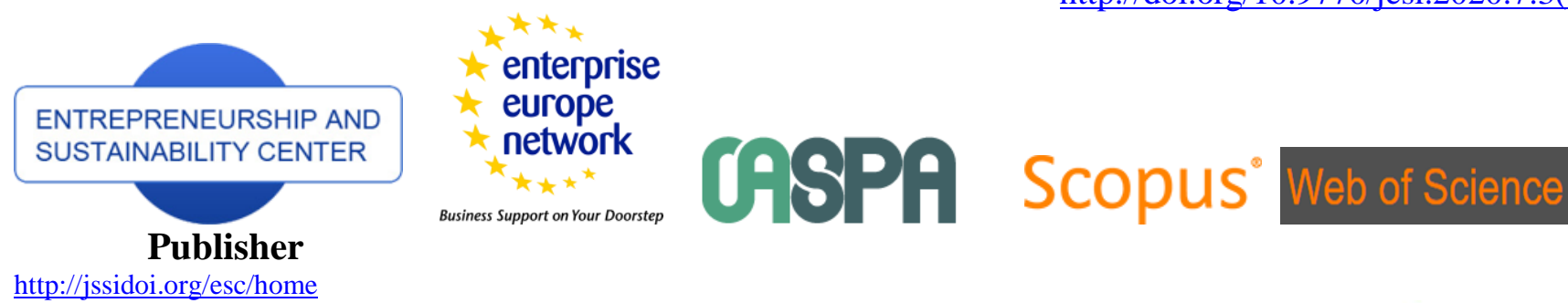

http://jssidoi.org/esc/home

\title{
EVALUATION OF ESCAPE ROOM COMPETITIVE POSITION IN POLISH MACRO REGIONS WITH 2D AND 1D STRATEGIC GROUP MAPS
}

\author{
Marzena Wójcik-Augustyniak ${ }^{1}$ Ewa Multan² \\ 1,2 Faculty of Social Sciences, University of Natural Sciences and Humanities, Siedlce, Poland

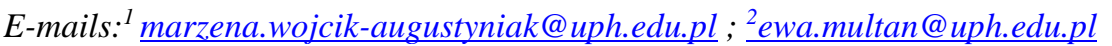

Received 18 October 2019; accepted 18 January 2020; published 30 March 2020

\begin{abstract}
For the purpose of this article a strategic analysis of the escape room sector in Poland has been carried out for the first time, using new variants of strategic group maps. The aim of the paper is to test the technique of multi-sector 2D (two-dimensional) strategic group maps and a new version of 1D (one-dimensional) strategic group maps for the analysis and evaluation of the competitive position of selected escape rooms in Polish macro regions in 2018. In addition, the paper proposes procedures for the development of new variants of strategic group maps, as well as recommendations to escape room owners and investors in particular parts of Poland. The main scientific problem of the article is to investigate to what extent new variants of strategic group maps can be applied in strategic analysis. The hypothesis assumes that 2D (two-dimensional) and 1D (one-dimensional) strategic group maps can have various applications in strategic analysis. The conclusions of the research conducted with the use of multi-sector 2D strategic group maps contain a partial evaluation, both horizontal and vertical, of the competitive position of escape rooms. Elements of differentiation strategy of an escape room, such as the minimum price for a room, its ranking in Lockme.pl, and the game difficulty level is taken into account. Using 1D strategic group maps the research makes it possible to evaluate the situation in escape rooms in Poland by their key stakeholders, i.e. owners and clients. 1D strategic group maps included in this paper present differences and similarities between the owners' and clients' opinions about the difficulty level of escape rooms. The recognition of the existence of those differences or similarities, whether the views converge or diverge, helps in the decision-making concerning future strategies.
\end{abstract}

Keywords: escape rooms, macro-regions (NUTS1), strategic analysis, 2D strategic group maps, 1D strategic group maps, stakeholders

Reference to this paper should be made as follows: Wójcik-Augustyniak, M., Multan, E. 2020. Evaluation of escape room competitive position in Polish macro regions with $2 \mathrm{~d}$ and 1d strategic group maps. Entrepreneurship and Sustainability Issues, 7(3), 1632-1652. https://doi.org/10.9770/jesi.2020.7.3(14)

JEL Classifications: L10, L25, L82, M13

\section{Introduction}

Carried out with popular techniques of business environment analysis, studies on a sector provide information on its competitive position to make better decisions about shaping differentiation strategy of Strategic Business Units

\footnotetext{
* The research was carried out under the research theme No. 499/18/S financed by a science grant provided by the Ministry of Science and Higher Education of Poland.
} 


\section{ENTREPRENEURSHIP AND SUSTAINABILITY ISSUES}

ISSN 2345-0282 (online) http://jssidoi.org/jesi/

2020 Volume 7 Number 3 (March)

http://doi.org/10.9770/jesi.2020.7.3(14)

(SBU). One of the techniques used for this purpose is strategic group maps. The classical version of this technique is described by foreign and Polish authors (Hunt, 1972; McGee, Thomas, 1986; Cool, Dierickx, 1993; Porter, 1994; Jeannet, Schreuder, 2015; Gierszewska, Romanowska, 2017; Wójcik-Augustyniak, Multan, 2017). According to the authors of this article an interesting solution to improve the classical 2D strategic group map, enriching its use in the evaluation of the competitive position, would be its multi-sector variant and onedimensional variant, incorporating assessments of the situation by different stakeholder groups.

The variant of multi-sector strategic group maps assumes that one map illustrates and analyses situation of the same type of business activities in several geographical sectors. This is a particularly interesting and useful solution for companies operating in local markets. The novelty of the multi-sector variant presented in this article is:

- procedure for developing multi-sector 2D strategic group maps,

- access to horizontal and vertical comparative analyses,

- recommendations about decision-taking on strategies and their implementation, taking into account various geographical areas.

The evaluation approach using 1D maps, on the other hand, is based on the comparison of different assessments of various stakeholder groups, with their opinion on one of the selected criteria of the competitive environment. It is part of a comprehensive evaluation of the competitive situation in a business sector. According to the authors a complete assessment of a competitive position in sector should consists of the following attempts: static, dynamic, and evaluating, all of which are described in one of papers on this topic (Wójcik-Augustyniak, Multan, 2017). The novelty of the evaluation approach presented in this article is:

- a model of 1D strategic group maps,

- procedure for deleloping 1D strategic group maps,

- opportunity to use 1D strategic group maps,

- a support to take decisions on the ongoing business strategy, taking into account key stakeholder groups.

Analysis of the competitive position of escape rooms (which are treated in this article as Strategic Business Units - SBU) in Poland, with new variants of strategic group maps is carried out for the regions of the NUTS 1 level.

The article is addressed to a wide range of managers of various types of organizations that operate in many markets or intend to start operations in new markets, and the used tool (2D strategic group map) may apply not only to NUTS 1, but also to other types of territorial division (e.g. NUTS 2, countries).

The article consists of 6 parts, such as: evolution of escape rooms sector, the NUTS classification in Poland, methods, the analysis of the escape room sector in macro regions of Poland wit usage of two variants of strategic group maps $2 \mathrm{D}$ and $1 \mathrm{D}$, and procedures.

\section{Evolution of escape rooms sector}

The beginning of escape room companies dates back to 1988, when the first game from the group of virtual ones based solely on the text appeared on the monitor screen. At that time the action of the game itself was enough for the player to enjoy it and to pursue its aim, which was to escape from a locked room. The essence of the escape game is to get out, which is possible only after fulfilling tasks and solving puzzles located in the room. With the development of information technology, activities of escape room games have become more varied and enriched with detailed graphics in the room. That has made them one of the so-called "point and click" games, with a player in front of the screen with a mouse in his or her hand. The need of a higher level of expertise and difficulty to solve puzzles during the game has led to an increase in interest among players using computers, smart phones, and tablets. No one expected in the beginning that the development of this type of game would turn into 


\section{ENTREPRENEURSHIP AND SUSTAINABILITY ISSUES}

ISSN 2345-0282 (online) http://jssidoi.org/jesi/

2020 Volume 7 Number 3 (March)

http://doi.org/10.9770/jesi.2020.7.3(14)

an escape from a real room. This meant that the game had become really realistic and players, leaving their computers behind, had to go personally to the mysterious room, trying their hand to check whether they were up to solving the tasks to be able to escape within the designated time (Lockme.pl).

The first game with a real life escape room was established in the Silicon Valley in 2006 and was created by computer programmers. The action content was inspired by the works of Agatha Christie. In 2007 Takao Kato opened the first escape room in Japan (Escape room, room escape, 2016). After that, since 2011 escape games have been set up in Singapore (Marinho, 2012) and Budapest. In the latter city an escape room was founded by the Parapark company, a Hungarian franchise, which later acted in 20 places in Europe and Australia (Bence, 2016). In 2012 a friend of Kato's brought the Real Escape Game to San Francisco (Cheng, 2014).

In time escape rooms have become popular in the United States, the United Kingdom, Canada, Israel, Japan, Taiwan, and mainland China. In 2015 the first evacuation games were offered to clients in South America, in Porto Alegre and São Paulo. In September 2017 there were already more than 8000 escape room businesses around the world (exitgames.co.uk 2017). Escape rooms at fixed locations were opened first in Asia, then in North America, Europe, Australia, New Zealand, Russia, and South America (Rospopina, 2015).

An escape room, which is a bit of a game, partly theatre, or an integration exercise, breaks records of popularity around the world. Such popularity on global markets has meant that during the last several years it has become more and more popular in Poland. The first Polish design was established in Wrocław in 2013 (Kowalik, 2015), and since 2014 companies have been set up throughout the country to construct rooms for playing an escape game (Lockme.pl).

Currently in any big city in Poland one can take advantage of a few rooms, or even of dozens of them, developed for complex activities. The rooms are varied widely for game plots. One can book rooms full of secrets, or scary ones. Rooms vary also in price, duration of the activities, number of persons involved, and difficulty level. Escape rooms are designed for the whole family and their friends to have fun. This is also a way to carry out corporate events, like networking activities for new employees, because many of the puzzles in rooms require teamwork and good communication between the players. So it is a great combination of fun with training, which can lead to better results at work. Escape rooms are a diverse mix of different mini-games, with a goal to bring the player to an end, that is, to escape from the room before the designated time (Lockme.pl).

For companies escape rooms can be very rewarding financially, due to their relatively low costs (Waterhouse, 2017) and quick, up to a year, return on investment (French, Shaw, 2015).

\section{The NUTS classification in Poland}

Due to the fact that the article is focused on business activities in local markets, it is appropriate to present a description of escape room companies in geographical terms. The authors have assumed that the simplest way to divide the territory of Poland for the purpose of this research is by using the existing territorial division of EU Member States into three regional levels with specific numbers of the population. This division, which is a geographical standard, is used for statistical purposes and is called the Classification of Territorial Units for Statistics, NUTS. The classification was established in order to collect, develop, and distribute comparable data for particular regional statistics throughout the European Union and for shaping regional policies of European Union countries. It is used to carry out analyses of the degree of socio-economic development of EU regions. The NUTS classification was introduced with the regulation of the European Parliament and of the Council of 26 May, 2003 (Regulation (EC) no 1059/2003), and went into force on 11 July 2003 (Classification of Territorial Units for Statistics). 


\section{ENTREPRENEURSHIP AND SUSTAINABILITY ISSUES}

ISSN 2345-0282 (online) http://jssidoi.org/jesi/

2020 Volume 7 Number 3 (March)

http://doi.org/10.9770/jesi.2020.7.3(14)

The NUTS classification divides each Member State of the European Union into territorial units: NUTS 1, NUTS 2, and NUTS 3. Territorial units of the NUTS 1 level are divided into territorial units of the NUTS 2 level, and these are divided into territorial units of the NUTS 3 level; one territorial unit can represent several NUTS levels. The assumption of the classification is that the units of a level with all Member States of the European Union should be similar to each other in terms of the population number.

The NUTS classification was formally introduced in Poland on November 26, 2005, at the time of the entry into force of the regulation of the European Parliament and of the Council amending Regulation on the establishment of the Classification of Territorial Units for Statistics (NUTS) by reason of the accession of the Czech Republic, Estonia, Cyprus, Latvia, Lithuania, Hungary, Malta, Polish, Slovenia, and Slovakia to the European Union (Regulation (EC) no 1888/2005). In the case of Poland, this classification has been applied since the time of Polish accession to the European Union on 1 May 2004. During the subsequent three revisions of NUTS between 2004 and 2015 the division of Poland into NUTS 1 and NUTS 2 units had not changed. What had changed was the division into NUTS 3 sub-regions. It was a result of the fourth revision of NUTS in 2016 (Commission Regulation (EU) 2016/2066) when the division of the country changed at all NUTS levels, with one new unit added to each level. Since January 1, 2018, 97 NUTS units has operated in Poland (The NUTS classification in Poland):

- NUTS 1 - macro-regions (with Poland's regions) - 7 units (Figure 1),

- NUTS 2 regions (with voivodships or their parts) - 17 units,

- NUTS 3-sub-regions (with counties) - 73 units.

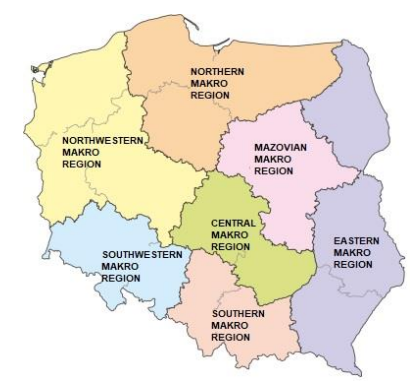

Fig.1. Division of Poland into NUTS 1 units

Source: The NUTS classification in Poland, 2018

\section{Methods}

The aim of the paper is to test the technique of multi-sector 2D (two-dimensional) strategic group maps and a new version of 1D (one-dimensional) strategic group maps for the analysis and evaluation of the competitive position of selected escape rooms in Polish macro regions in 2018. The main scientific problem of the article is to investigate to what extent new variants of strategic group maps can be applied in strategic analysis. The hypothesis assumes that 2D (two-dimensional) and 1D (one-dimensional) strategic group maps can have various applications in strategic analysis.

For the purposes of this article the escape rooms sector in Poland has been studied for the first time. The study has a pilot nature due to the fact that its main purpose is to test a new version of 1D strategic group maps and a new kind of 2D strategic group maps with a multi sector approach (Multan, Wójcik-Augustyniak, 2016).

Assuming that a sector, according to the classical definition of M.E. Porter, is "part of an industry that groups companies manufacturing similar products or providing similar services, selling them in the same geographic 
market" (Porter 1994, p. 23), the authors have assumed that in the case of escape rooms there are seven territorial sectors, corresponding to seven macro regions (statistical classification of the NUTS 1 level). This approach has for the first time made it possible to present all those geographical sectors in Poland on one 2D map. In order to test the technique of multi-sector 2D strategic group maps and 1D strategic group maps in the analysis and evaluation of the competitive position of selected escape rooms, the authors use the current list with 328 escape room entities in Poland, with 914 rooms available on the lockme website (Lockme.pl). With regard to the aim of the research the authors have applied the statistical method of purposive random sampling:

- purposive selection of cities for further analyses (capital cities of all voivodships in all NUTS 1),

- random selection in the case of 2D and 1D maps (selecting the first escape room from the list in the capitals of voivodships in macro-regions and then every 10-11 th from this list) (lockme.pl/ranking).

In each of the analysed cities $10 \%$ of the escape rooms have been selected, which means that $10 \%$ of the total number of 678 rooms is rounded up to 69 rooms.

The authors propose the following pairs of criteria that make up the configuration of 2D strategic group maps:

- the first pair of criteria: X: macro region, i.e. location/ Y: the minimum price for a room,

- the second pair of criteria: $\mathrm{X}$ : macro region, i.e. location/Y: position of the room in the ranking.

In the article three significance levels of criteria of differentiation strategy of an escape room are applied to the minimum price for a room and to the place of a room in the ranking (Table 1).

Table 1. Significance levels with differentiation strategy elements of an escape room: the minimum price for a room and the position of a room in the ranking

\begin{tabular}{|c|c|c|c|c|c|}
\hline $\begin{array}{c}\text { Significance } \\
\text { level (1-3) }\end{array}$ & $\begin{array}{c}\text { Significance } \\
\text { level name }\end{array}$ & $\begin{array}{c}\text { Significance } \\
\text { level range }\end{array}$ & Significance level description & $\begin{array}{c}\text { Minimum price } \\
\text { for a room (PLN) }\end{array}$ & $\begin{array}{c}\text { The position of the } \\
\text { room in the ranking }\end{array}$ \\
\hline 1 & Low & $(0-33.33)$ & $\begin{array}{l}\text { with the share of differentiation } \\
\text { elements less than } 33.33\end{array}$ & up to 66 & over 640 \\
\hline 2 & Medium & $<33.33-66.66)$ & $\begin{array}{l}\text { with the share of differentiation } \\
\text { elements from } 33.33 \text { to } 66,66\end{array}$ & from 67 to 133 & from 320 to 639 \\
\hline 3 & High & $<66.66-100)$ & $\begin{array}{l}\text { with the share of differentiation } \\
\text { elements from } 66.66 \text { to } 100\end{array}$ & over 134 & under 319 \\
\hline
\end{tabular}

Source: own elaboration

In addition, for the purposes of the construction of $2 \mathrm{D}$ strategic group maps the third pair of criteria is used: $\mathrm{X}$ : macro-region / Y: declared difficulty level of the room (declared by the room's owner). For the seven macro regions a seven-point scale has been adopted (Table 2), while for the declared difficulty level of a room a fivepoint scale is used (Table 3).

Table 2. Differentiation strategy elements of an escape room: the macro-region

\begin{tabular}{|c|c|}
\hline Scale & Macro region \\
\hline 1 & Central \\
\hline 2 & Southwestern \\
\hline 3 & Mazovian \\
\hline 4 & Eastern \\
\hline 5 & Northern \\
\hline 6 & Northwestern \\
\hline 7 & Southern \\
\hline
\end{tabular}

Source: own elaboration 
For the purposes of the construction of 1D strategic group maps the following criteria are proposed: the declared difficulty level and the evaluated difficulty level assessed by clients, both with a five-point scale (Table 3).

Table 3. Differentiation strategy elements of an escape room: the declared difficulty level and the evaluated difficulty level

\begin{tabular}{|c|c|c|}
\hline Scale & Declared difficulty level & Evaluated difficulty level \\
\hline 1 & absolute beginner (AB) & very easy (VE) \\
\hline 2 & beginner (B) & easy (E) \\
\hline 3 & intermediate (I) & average (A) \\
\hline 4 & advanced (A) & difficult (D) \\
\hline 5 & proficient (O) & very difficult (VD) \\
\hline
\end{tabular}

Source: own elaboration

In parts 5 and 6 of the article, the analysis of the escape rooms sector is presented. Thanks to this it will be possible to state to what extent strategic group map 2D and strategic group map 1D are applicable in strategic analysis. It will allow to solve the research problem and verify the research hypothesis.

\section{The analysis of the escape rooms sector in macro regions Polish using multi-sector 2D strategic group maps}

This article attempts to use the technique of strategic group maps for the analysis of the competitive position in the escape rooms sector. It is the first time a variant of the multi-sector strategic group maps has been used this way. So far, classical 2D maps have illustrated the situation in one separate geographical region (according to Porter's definition). However, the authors are trying to demonstrate that it is possible to present competitive situation in different locations. This approach may be applicable to the analysis of a sector in which companies operate in local markets. It is possible to provide an image of the SBU competitive situation on one map, depending on the area of activity. Table 4 presents evaluation data on escape rooms in macro regions of Poland in 2018.

Table 4. The evaluation criteria of the escape rooms sector in macro-regions in Poland in August 8, 2018

\begin{tabular}{|c|c|c|c|c|c|c|c|c|c|}
\hline \multirow{2}{*}{$\begin{array}{c}\text { The name of the } \\
\text { room }\end{array}$} & \multirow{2}{*}{ City } & \multirow{2}{*}{$\begin{array}{c}\text { NUTS } 1 \\
\text { macro region }\end{array}$} & \multicolumn{2}{|c|}{$\begin{array}{l}\text { Position of the room } \\
\text { in the ranking }\end{array}$} & \multicolumn{2}{|c|}{$\begin{array}{l}\text { Minimum price for } \\
\text { the room }\end{array}$} & \multicolumn{2}{|c|}{ Difficulty level } & \multirow{2}{*}{$\begin{array}{c}\text { Market share } \\
\text { (number of } \\
\text { votes) }\end{array}$} \\
\hline & & & level & evaluation & $\begin{array}{l}\text { level } \\
\text { (PLN) }\end{array}$ & evaluation & level & evaluation & \\
\hline Desolate Garage & Kielce & Central & 692 & 1 & 79 & 2 & A & 4 & 9 \\
\hline Prologue & Łódź & Central & 58 & 3 & 200 & 3 & I & 3 & 176 \\
\hline $\begin{array}{l}\text { Behind the Scenes } \\
\text { of Hollywood }\end{array}$ & Lódź & Central & 256 & 3 & 120 & 2 & I & 3 & 12 \\
\hline Manuscript & Łódź & Central & 382 & 2 & 120 & 2 & $\mathrm{~A}$ & 4 & 75 \\
\hline Crime & Łódź & Central & 502 & 2 & 79 & 2 & $\mathrm{~B}$ & 2 & 52 \\
\hline Haunted Closet & Łódź & Central & 637 & 2 & 99 & 2 & $\mathrm{I}$ & 3 & 30 \\
\hline Orphanage & Opole & Southwestern & 568 & 2 & 120 & 2 & $\mathrm{~A}$ & 4 & 14 \\
\hline Insanity & Wrocław & Southwestern & 6 & 3 & 181 & 2 & I & 3 & 84 \\
\hline Necromancer & Wrocław & Southwestern & 65 & 3 & 135 & 3 & I & 3 & 52 \\
\hline $\begin{array}{l}\text { Abandoned Puppet } \\
\text { Theatre }\end{array}$ & Wrocław & Southwestern & 221 & 3 & 120 & 2 & B & 2 & 191 \\
\hline Amnesia & Wrocław & Southwestern & 341 & 2 & 100 & 2 & $\mathrm{~B}$ & 2 & 73 \\
\hline Doc's Surgery & Wrocław & Southwestern & 517 & 2 & 100 & 2 & $\mathrm{~B}$ & 2 & 70 \\
\hline Laser & Wrocław & Southwestern & 774 & 1 & 99 & 2 & $\mathrm{~A}$ & 4 & 17 \\
\hline Strange Circus & Warszawa & Mazovian & 4 & 3 & 150 & 3 & $\mathrm{~A}$ & 4 & 136 \\
\hline
\end{tabular}


ENTREPRENEURSHIP AND SUSTAINABILITY ISSUES

ISSN 2345-0282 (online) http://jssidoi.org/jesi/

2020 Volume 7 Number 3 (March)

http://doi.org/10.9770/jesi.2020.7.3(14)

\begin{tabular}{|c|c|c|c|c|c|c|c|c|c|}
\hline Trapped in a Bunker & Warszawa & Mazovian & 59 & 3 & 120 & 2 & A & 4 & 105 \\
\hline Sex Room & Warszawa & Mazovian & 109 & 3 & 90 & 2 & $\mathrm{~B}$ & 2 & 997 \\
\hline Desert Island & Warszawa & Mazovian & 149 & 3 & 99 & 2 & $\mathrm{~B}$ & 2 & 379 \\
\hline Room of Puzzles & Warszawa & Mazovian & 192 & 3 & 120 & 2 & $\mathrm{~B}$ & 2 & 36 \\
\hline House in the Jungle & Warszawa & Mazovian & 268 & 3 & 179 & 3 & $\mathrm{I}$ & 3 & 94 \\
\hline ShowShank & Warszawa & Mazovian & 303 & 3 & 149 & 3 & I & 3 & 73 \\
\hline Time Machine & Warszawa & Mazovian & 417 & 2 & 150 & 3 & $\mathrm{~B}$ & 2 & 131 \\
\hline Sherlocked & Warszawa & Mazovian & 485 & 2 & 80 & 2 & $\mathrm{~B}$ & 2 & 70 \\
\hline Cosmic Odyssey & Warszawa & Mazovian & 551 & 2 & 110 & 2 & A & 4 & 173 \\
\hline $\begin{array}{l}\text { Return of the } \\
\text { Dragons }\end{array}$ & Warszawa & Mazovian & 702 & 1 & 159 & 3 & A & 4 & 40 \\
\hline Old Circus & Warszawa & Mazovian & 920 & 1 & 88 & 2 & $\mathrm{~B}$ & 2 & 5 \\
\hline Pharaoh's Curse & Białystok & Eastern & 320 & 2 & 80 & 2 & $\mathrm{I}$ & 3 & 15 \\
\hline $\begin{array}{l}\text { Antique dealer's } \\
\text { room }\end{array}$ & Lublin & Eastern & 290 & 3 & 99 & 2 & A & 4 & 61 \\
\hline $\begin{array}{l}\text { CSI - Crime Scene } \\
\text { Investigation }\end{array}$ & Lublin & Eastern & 694 & 1 & 5 & 1 & I & 3 & 28 \\
\hline $\begin{array}{l}\text { The Attic of } \\
\text { Columbus }\end{array}$ & Lublin & Eastern & 864 & 1 & 99 & 2 & A & 4 & 10 \\
\hline Pharaoh's Tomb & Rzeszów & Eastern & 101 & 3 & 100 & 2 & $\mathrm{I}$ & 3 & 234 \\
\hline $\begin{array}{l}\text { Nautilus - Undersea } \\
\text { Adventure }\end{array}$ & Bydgoszcz & Northern & 1 & 3 & 100 & 2 & A & 4 & 240 \\
\hline Angor Wat Depths & Bydgoszcz & Northern & 52 & 3 & 80 & 2 & $\mathrm{I}$ & 3 & 65 \\
\hline Nuclear Reactor & Bydgoszcz & Northern & 174 & 3 & 60 & 1 & $\mathrm{I}$ & 3 & 23 \\
\hline Dream Factory & Bydgoszcz & Northern & 449 & 2 & 100 & 2 & $\mathrm{~B}$ & 2 & 13 \\
\hline What a Circus & Gdańsk & Northern & 126 & 3 & 99 & 2 & $\mathrm{I}$ & 3 & 114 \\
\hline Escape from Prison & Gdańsk & Northern & 223 & 3 & 129 & 2 & A & 4 & 260 \\
\hline Shelter & Gdańsk & Northern & 391 & 2 & 80 & 2 & $\mathrm{~A}$ & 4 & 66 \\
\hline $\begin{array}{l}\text { Ghost from Alt } \\
\text { Allenstein }\end{array}$ & Olsztyn & Northern & 338 & 2 & 99 & 2 & A & 4 & 7 \\
\hline Time Machine & Toruń & Northern & 59 & 3 & 90 & 2 & $\mathrm{~A}$ & 4 & 95 \\
\hline Scary Circus & Toruń & Northern & 249 & 3 & 79 & 2 & $\mathrm{I}$ & 3 & 21 \\
\hline Guantanamo & $\begin{array}{c}\text { Gorzów } \\
\text { Wielkopolski }\end{array}$ & Northwestern & 618 & 2 & 80 & 2 & B & 2 & 14 \\
\hline Connoisseur & Poznań & Northwestern & 8 & 3 & 130 & 2 & $\mathrm{I}$ & 3 & 57 \\
\hline Backstage & Poznań & Northwestern & 67 & 3 & 100 & 2 & $\mathrm{I}$ & 3 & 64 \\
\hline Magic School & Poznań & Northwestern & 167 & 3 & 79 & 2 & $\mathrm{~B}$ & 2 & 53 \\
\hline Debt & Poznań & Northwestern & 239 & 3 & 100 & 2 & $\mathrm{~A}$ & 4 & 27 \\
\hline Interrogation Room & Poznań & Northwestern & 362 & 2 & 100 & 2 & $\mathrm{~B}$ & 2 & 4 \\
\hline Flora Mortis & Poznań & Northwestern & 455 & 2 & 85 & 2 & $\mathrm{I}$ & 3 & 42 \\
\hline Short but Crazy & Poznań & Northwestern & 548 & 2 & 99 & 2 & $\mathrm{I}$ & 3 & 20 \\
\hline Shelter & Poznań & Northwestern & 794 & 1 & 100 & 2 & $\mathrm{~B}$ & 2 & 2 \\
\hline Nautilus & Szczecin & Northwestern & 73 & 3 & 99 & 2 & $\mathrm{I}$ & 3 & 77 \\
\hline Se7en & Szczecin & Northwestern & 198 & 3 & 80 & 2 & $\mathrm{~A}$ & 4 & 104 \\
\hline Grey’s Room & Szczecin & Northwestern & 568 & 2 & 100 & 2 & $\mathrm{~B}$ & 2 & 24 \\
\hline $\begin{array}{l}\text { Sherlock - Holly } \\
\text { Grail }\end{array}$ & Szczecin & Northwestern & 895 & 1 & 69 & 2 & I & 3 & 1 \\
\hline $\begin{array}{l}\text { Workshop of a } \\
\text { School Scientist }\end{array}$ & Zielona Góra & Northwestern & 563 & 2 & 99 & 2 & A & 4 & 21 \\
\hline Moriarty Limited & Katowice & Southern & 3 & 3 & 99 & 2 & $\mathrm{I}$ & 3 & 268 \\
\hline Think like a Hunter & Katowice & Southern & 236 & 3 & 99 & 2 & $\mathrm{I}$ & 3 & 33 \\
\hline $\begin{array}{l}\text { Father Leon- the } \\
\text { exorcist's, chapel }\end{array}$ & Katowice & Southern & 383 & 2 & 89 & 2 & B & 2 & 83 \\
\hline PsychoEd & Katowice & Southern & 691 & 1 & 99 & 2 & $\mathrm{I}$ & 3 & 9 \\
\hline Escape da Vinci & Kraków & Southern & 20 & 3 & 100 & 2 & $\mathrm{I}$ & 3 & 212 \\
\hline
\end{tabular}




\section{ENTREPRENEURSHIP AND SUSTAINABILITY ISSUES}

ISSN 2345-0282 (online) http://jssidoi.org/jesi/

2020 Volume 7 Number 3 (March)

http://doi.org/10.9770/jesi.2020.7.3(14)

\begin{tabular}{|l|c|c|c|c|c|c|c|c|c|}
\hline Disgusting Hotel & Kraków & Southern & 86 & 3 & 100 & 2 & I & 3 & 59 \\
\hline Ei! It's my beat & Kraków & Southern & 260 & 3 & 90 & 2 & I & 3 & 60 \\
\hline Prisoner & Kraków & Southern & 452 & 2 & 90 & 2 & B & 2 & 149 \\
\hline $\begin{array}{l}\text { Star Wars - New } \\
\text { Adventure }\end{array}$ & Kraków & Southern & 535 & 2 & 88 & 2 & B & 2 & 26 \\
\hline Laboratory & Kraków & Southern & 701 & 1 & 99 & 2 & AB & 1 & 64 \\
\hline AmberGold & Kraków & Southern & 832 & 1 & 99 & 2 & I & 3 & 12 \\
\hline \multicolumn{1}{|c}{ Total } & - & - & - & - & - & - & - & - & $\mathbf{5 8 3 1}$ \\
\hline
\end{tabular}

Source: own elaboration based on www.Lockme.pl

Due to the fact that among the total number of 678 rooms there were also ones being in preparation, only 65 escape rooms were considered for further analyses. It is worth adding that the largest number of 678 escape rooms in Poland was located in Warsaw - 129 (Mazovian macro region). This is due to the fact that the capital city of Warsaw is the largest in terms of population and the richest city in Poland, taking into account GDP per capita (Koza 2018, for: Regional Innovation Scoreboard 2017).

After the identification and evaluation of the criteria in the sector of escape rooms divided into macro regions, the next stage is to build a 2D strategic group map with selected pairs of criteria (in accordance with the provisions set out in tables 2 and 3), and then to incorporate the evaluation (with the scale of 1-3 and 1-7) on the $X$ and $Y$ axes of the coordinate system for individual rooms from Tab. 4. The result is a presentation of the situation in a geographical region with a strategic group map (figures 2-4). The market share is presented using circles of different diameters reflecting the number of votes of escape room clients. The data of multi-sector 2D strategic group maps can be analysed horizontally and vertically.

Strategic horizontal analysis allows determining what competitive situation of the rooms in various macro regions is, taking into account the number of strategic groups, the sum of the market shares of these groups, and the total number of rooms offering services at all levels of the analyzed criterion of differentiation strategy in the macro region. Strategic vertical analysis allows determining what competitive situation of the rooms in various macro regions is, taking into account the number of strategic groups, the sum of the market shares of these groups, and the total number of rooms offering services at the same level of the analyzed criterion of differentiation strategy in the macro-region.

Analysis of the data in the Figure 2 shows that in NUTS 1 geographical sectors of escape rooms in Poland there are eight strategic groups and four independent strategic business units (SBUs).

The number of escape rooms with the highest total market share of strategic groups offering services at level 2 of the minimum price (67-133 PLN) is the largest. This level can therefore be regarded as the greatest price advantage in all Polish macro regions. The number of rooms offering services at level 2 of the minimum price is 56 , which represents $86 \%$ of the analyzed rooms, while the total market share of this level is $87.54 \%$.

Vertical analysis indicates that in the majority of macro regions there is usually one strategic group. There are two strategic groups (C and D) in the Mazovian macro region only. In the Central, Southwestern, Eastern and Northern macro regions there are independent SBUs. In the richest macro regions: Mazovian, Southwestern, and Central, there are escape rooms offering services at level 3 of the minimum price (over 134 PLN), while in the Eastern and Northern macro regions they offer services at level 1 of the minimum price (66 PLN). 


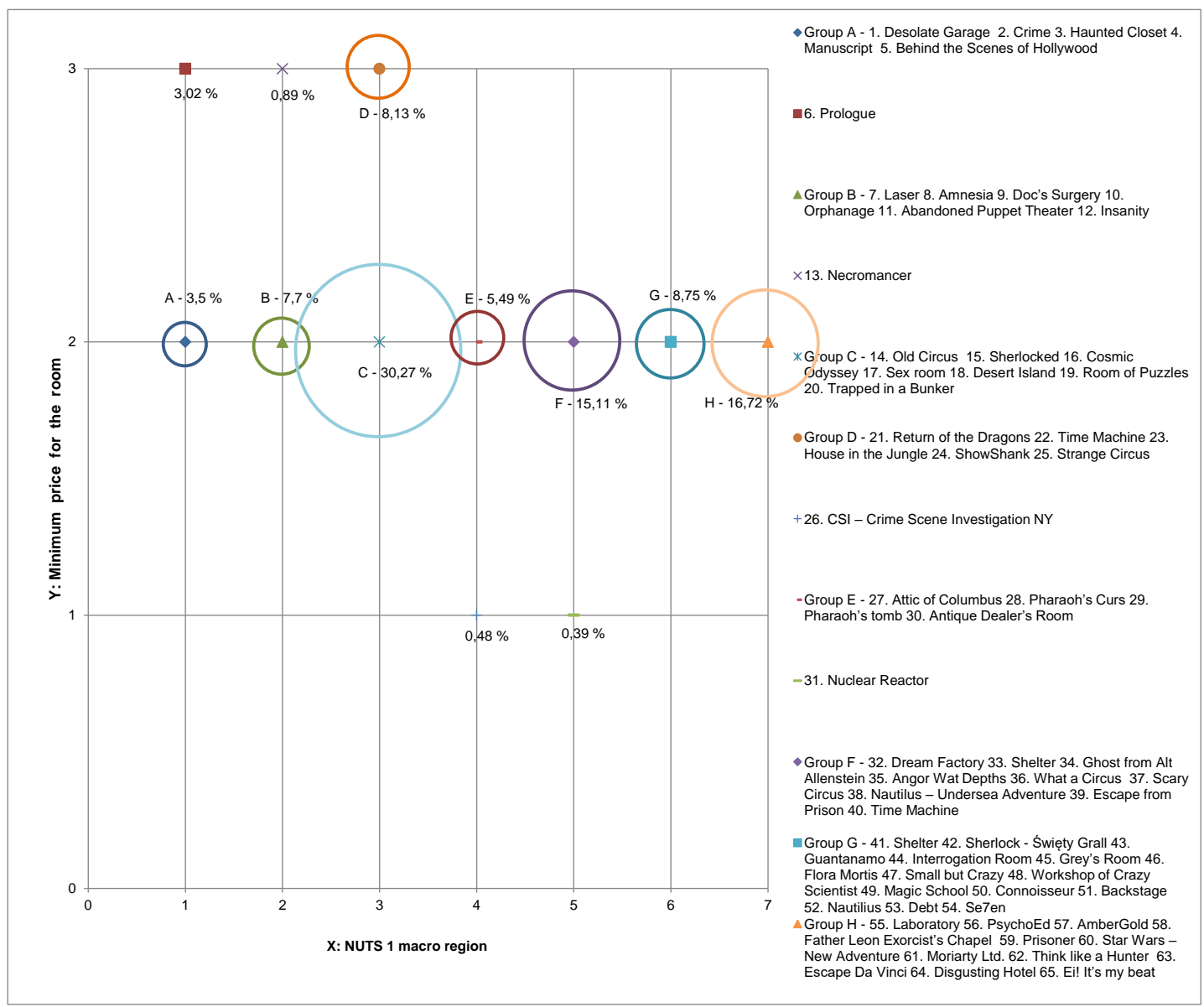

Fig.2. 2D strategic group map of escape rooms in macro regions of Poland -the $1^{\text {st }}$ pair of factors

Source: own elaboration based on Lockme.pl

Rooms located in the Mazovian, Southern, and Northern macro regions have the highest market share.

From the point of view of owners intending to open new escape rooms in other locations and of investors who want to enter this sector, it may profitable to open rooms with level 2 of the minimum price in Central and the Southwestern macro regions where there is a relatively small number of rooms, or those of level 3 which are independent SBUs with a low market share.

In the Eastern macro region the best way may be to open escape rooms with level 1 or/and level 2 of the minimum price. In this macro region there are only a few rooms, but because of a lower income of potential clients there, the prices for this type of entertainment would have to be lower than in other, richer macro regions of Poland.

The escape room data presented in Figure 3 show that in all NUTS 1 geographical regions there are 17 strategic groups and 4 independent SBUs. The largest number of strategic groups with the highest total market share offer services at level 3, with the position below 319 in the ranking. This level can be considered the biggest advantage of a room in the ranking in all Polish macro regions. The best rooms in the ranking are visited by clients who, sharing their opinions, encourage others to use the services of these rooms. 


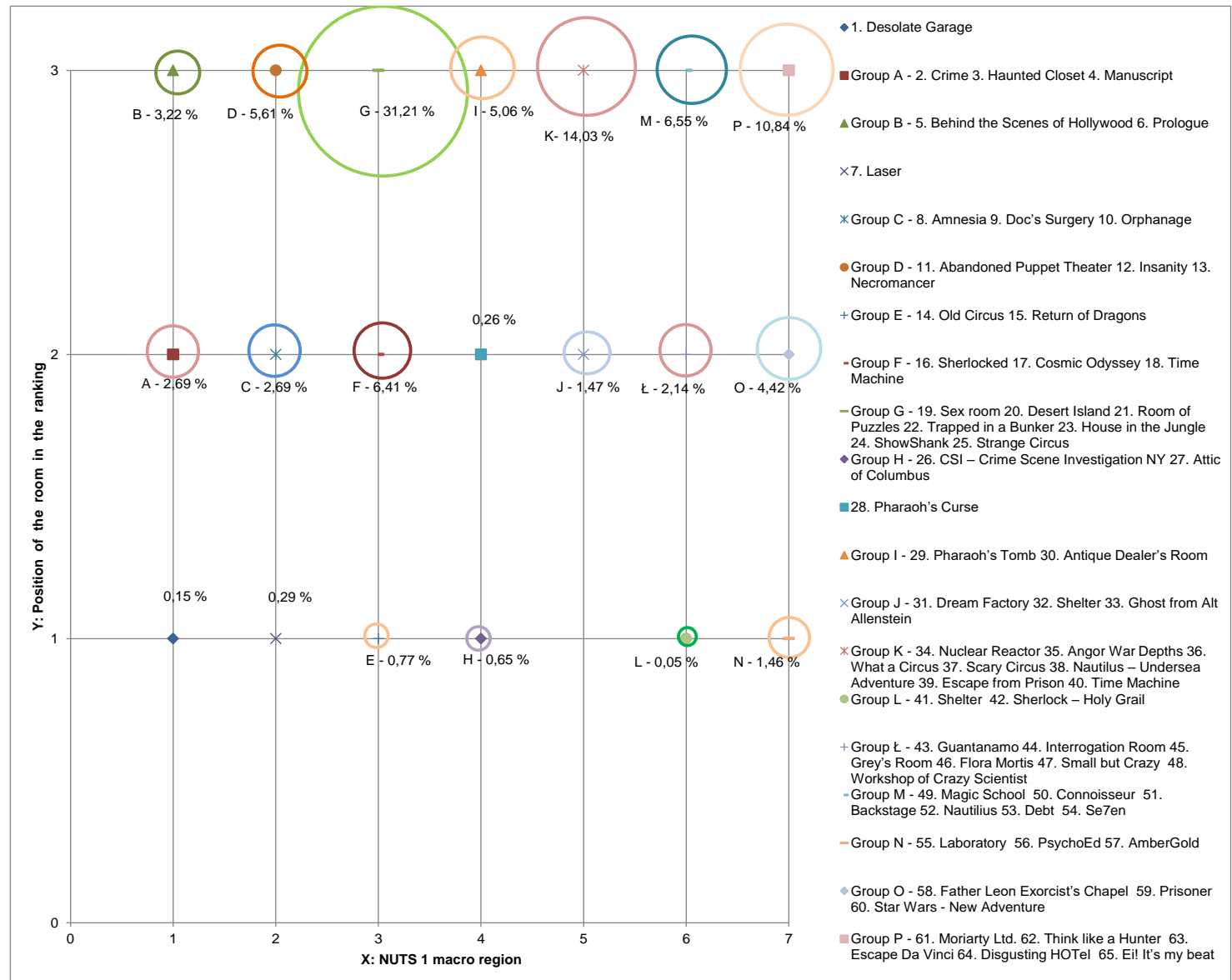

Fig. 3. 2D strategic group map of escape rooms in macro regions of Poland -the $2^{\text {nd }}$ pair of factors

Source: own elaboration based on Lockme.pl

The number of rooms with the highest ranking (level 3) is 32, which represents $49 \%$ of the analyzed rooms, while the total market share of level 3 in the ranking is $76.52 \%$ of those included in the study. All rooms of level 2, with the position in the ranking from 320 to 639 , accounted for $20.08 \%$ of the market share, with the number of rooms equal to 22 (34\% of the analyzed rooms). There are 11 companies offering services with level 1 with the position below 640 in the ranking, representing $17 \%$ of the analyzed rooms.

The rooms which are lower in the ranking are usually those with a shorter time on the market, and therefore they have a lower chance to attract a high number of clients. Vertical analysis shows that in the majority of macro regions there are two or three strategic groups of escape rooms or independent SBUs. In the Mazovian macro region there are three strategic groups $(\mathrm{E}, \mathrm{F}$, and $\mathrm{G})$, with the largest total number of 12 rooms, the highest combines market share of $38.39 \%$. This macro region constitutes the largest market share of the number of escape rooms with level 3 in the ranking $(31.21 \%)$.

The number of rooms with the highest ranking (level 3) is 32, which represents $49 \%$ of the analyzed rooms, while the total market share of level 3 in the ranking is $76.52 \%$ of those included in the study. All rooms of level 2, with the position in the ranking from 320 to 639 , accounted for $20.08 \%$ of the market share, with the number of rooms equal to 22 (34\% of the analyzed rooms). There are 11 companies offering services with level 1 with the position below 640 in the ranking, representing $17 \%$ of the analyzed rooms. 
The rooms which are lower in the ranking are usually those with a shorter time on the market, and therefore they have a lower chance to attract a high number of clients. Vertical analysis shows that in the majority of macro regions there are two or three strategic groups of escape rooms or independent SBUs. In the Mazovian macro region there are three strategic groups (E, F, and $\mathrm{G}$ ), with the largest total number of 12 rooms, the highest combines market share of $38.39 \%$. This macro region constitutes the largest market share of the number of escape rooms with level 3 in the ranking (31.21\%).

Analysis of the data presented in Figure 4 shows that in these geographical sectors (NUTS 1) there are 17 strategic groups and 3 independent SBUs.

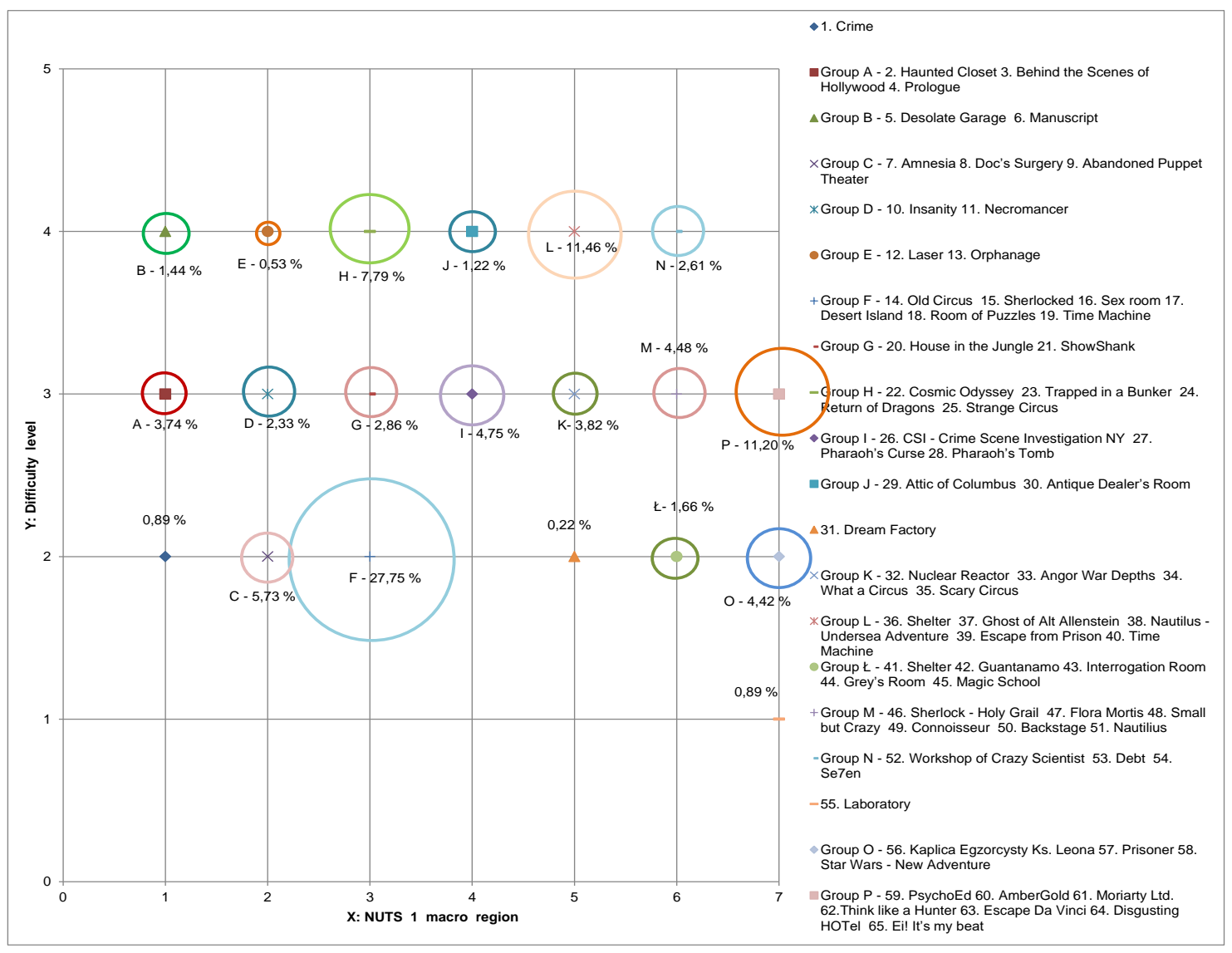

Fig. 4. 2D strategic group map of escape rooms in macro regions of Poland - the $3^{\mathrm{d}}$ pair of factors

Source: own elaboration based on Lockme.pl

In terms of the market share the largest group are the rooms whose owners have declared difficulty level 2 (for beginners). The total share of such rooms in all macro regions is $41.56 \%$, and the number of rooms is 19 (29\% of the analyzed rooms). The largest group is made up of escape rooms that declare difficulty level 3 (for intermediate clients). Their number is 27 , which is $41.5 \%$ of all analyzed rooms, and their combined market share is $33.18 \%$.

It must therefore be assumed that the rooms in all macro regions with the declared level of difficulty for beginners and intermediate players make the biggest profit. In fact there is a lack of rooms at the declared 1 and 5 levels (for 


\section{ENTREPRENEURSHIP AND SUSTAINABILITY ISSUES}

ISSN 2345-0282 (online) http://jssidoi.org/jesi/

2020 Volume 7 Number 3 (March)

http://doi.org/10.9770/jesi.2020.7.3(14)

absolute beginners and for proficient players), but there is one room for absolute beginners among the escape rooms.

Vertical analysis of strategic group maps reveals that in the Mazovian macro region rooms for beginners are the most popular (six rooms with the largest market share of 27.75\%), while those for advanced clients (4) constitute only $7.79 \%$. The relatively small difference in numbers does not translate proportionally to a small difference in market shares.

Clients in the Northern macro region prefer complex puzzles for advanced users mostly, while players in the Southern one prefer rooms of average difficulty (level 3). It seems that the declared difficulty level can evolve from the lowest up to the highest as the life expectancy of the service rises, and the owners acquire the knowledge and experience, or from the very beginning they declare the level of room difficulty (sometimes in a subjective way), and then change it when the experience and knowledge of the clients taking part in the game rise.

In terms of the market share the largest group are the rooms whose owners have declared difficulty level 2 (for beginners). The total share of such rooms in all macro regions is $41.56 \%$, and the number of rooms is 19 (29\% of the analyzed rooms). The largest group is made up of escape rooms that declare difficulty level 3 (for intermediate clients). Their number is 27 , which is $41.5 \%$ of all analyzed rooms, and their combined market share is $33.18 \%$.

It must therefore be assumed that the rooms in all macro regions with the declared level of difficulty for beginners and intermediate players make the biggest profit. In fact there is a lack of rooms at the declared 1 and 5 levels (for absolute beginners and for proficient players), but there is one room for absolute beginners among the escape rooms.

Vertical analysis of strategic group maps reveals that in the Mazovian macro region rooms for beginners are the most popular (six rooms with the largest market share of $27.75 \%$ ), while those for advanced clients (4) constitute only $7.79 \%$. The relatively small difference in numbers does not translate proportionally to a small difference in market shares.

Clients in the Northern macro region prefer complex puzzles for advanced users mostly, while players in the Southern one prefer rooms of average difficulty (level 3). It seems that the declared difficulty level can evolve from the lowest up to the highest as the life expectancy of the service rises, and the owners acquire the knowledge and experience, or from the very beginning they declare the level of room difficulty (sometimes in a subjective way), and then change it when the experience and knowledge of the clients taking part in the game rise.

The research presented in part 5 allowed for positive verification of the research hypothesis which assumed that 2D (two-dimensional) strategic group map can have various applications in strategic analysis.

In order to compare opinions and find out whether there is an agreement (or lack of it) in the evaluation of the difficulty level between owners and clients the technique of 1D strategic groups maps is used.

\section{The analysis of the escape room sector in macro regions of Poland using a variant of 1D strategic group maps}

1D strategic group maps are applied in this research to carry out detailed analyses of escape room data in all macro regions of Poland. A proposed variant of 1D strategic group maps takes into account the evaluation of one criterion in one dimension by various stakeholder groups. Stating, after I. Figurska, that "Using only internal sources of knowledge in the process of building a competitive position by the organization is not enough", and that the organization's clients are one of the external sources of knowledge, thanks to which the organization can 
gain knowledge about their "changing needs, perceptions company and its products, etc." (Figurska 2014: 211), in the escape room sector the classical version of 2D strategic group maps is enhanced with objective and subjective evaluation of the difficulty level by owners and clients.

In this article, the technique of 1D strategic groups maps is tested to analyze the position of a sector in seven macro regions in 2018. That demonstrates divergence or convergence of opinions among different stakeholder groups. The purpose of the 1D strategic groups map (Figure 5) is to adjust the existing strategy to a situation when there are divergent evaluations of variables by key stakeholders.

Divergence is a situation in which there is a dissimilarity in the evaluation of criteria/variables made by two external and/or internal stakeholder groups (the field of divergence). Convergence is a situation in which there is a similarity in the evaluation of criteria/variables made by two external and/or internal stakeholder groups (the field of convergence).

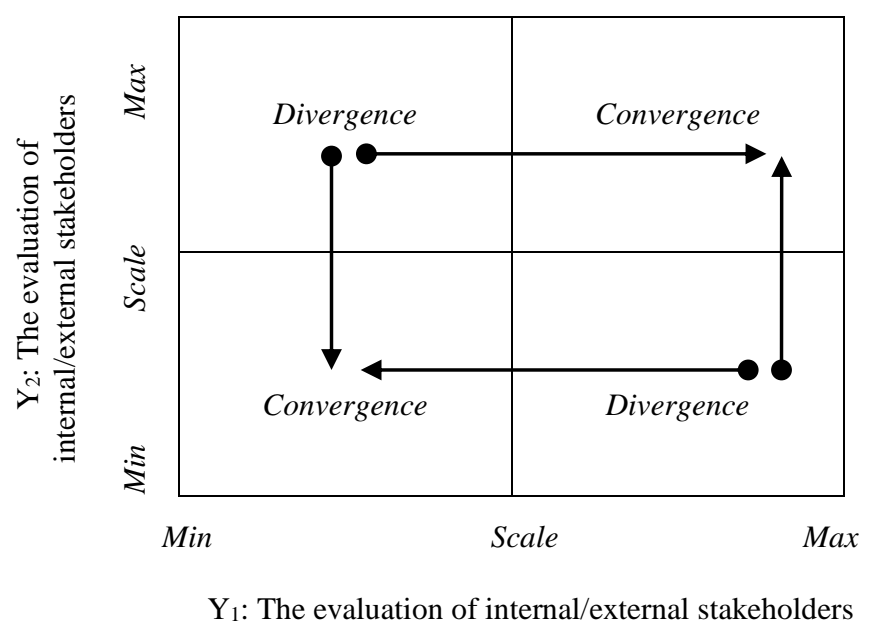

Fig. 5. 1D strategic group map with opinions of various stakeholder groups

Source: own elaboration

On coordinate axes a scale can be adopted, for example, using numbers (from 1 to 5 or from 1 to 10). To build a 1D matrix model the authors proposed the following configuration of variables/criteria assessed by two groups of stakeholders, i.e. owners and clients:

$-Y_{1}$ : the owner's evaluation (the owner-declared level of difficulty),

$-Y_{2}$ : the clients' evaluation (the client-evaluated level of difficulty).

After the identification and evaluation of the criteria in the macro regions, the next stage is to build a 1D strategic group map with selected pairs of criteria (in accordance with the provisions set out in table 3), and then to incorporate the evaluation (with the scale of 1-5) on the $Y_{1}$ and $Y_{2}$ axes of the coordinate system for individual escape rooms from Table 4.

In order to test the new variant of 1D strategic group map, an analysis of the competitive situation in escape rooms sector in three selected macro-regions of Poland: the Mazovian, the Northern and the Southern was conducted, thus presenting the diversity of the situation in the geographical terms.

Examples of 1D strategic group maps of all macro regions in Poland are presented in figures 6-8. 
The data presented in Figure 6 show that the escape rooms in the Southern macro region are in the fields of divergence and convergence in the evaluation of the difficulty level. On the strategic group map there are two strategic groups and two independent SBUs. Group A, located in the convergence field, has the largest share $(11.21 \%)$ and includes the largest number of analyzed rooms (7). Group B consists of two rooms (Father Leon the Exorcist's Chapel, Star Wars - New Adventure), with a market share of 1.69\%. Two rooms which are independent SBUs with the share of $2.56 \%$ and $1.1 \%$ (Prisoner and Laboratory) are located in the divergence field. The total share of rooms in the divergence field is $5.35 \%$. A low market share of rooms with divergence in the evaluation of the difficulty level should be a signal for the owners to change the strategy by changing the difficulty level to make it adequate to clients, offering a more difficult game (new puzzles, more complex puzzles, short-time games, etc.), or an easier one.

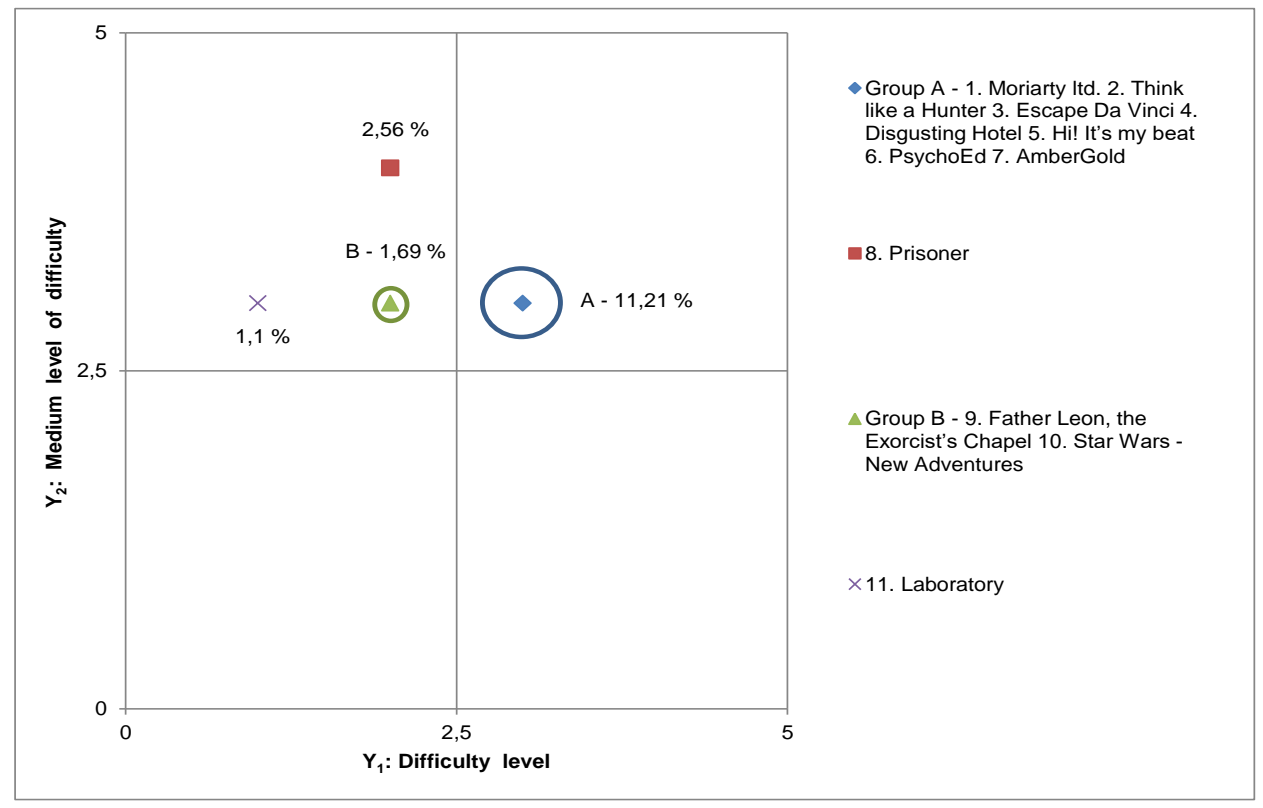

Fig. 6. 1D strategic group map of escape rooms in the Southern macro region of Poland

Source: own elaboration based on Lockme.pl

Based on the data presented in Figure 7, it can be concluded that the analyzed escape rooms in the Mazovian macro region are located in convergence and divergence fields in the evaluation of the difficulty level. On the map there is one strategic group A composed of three rooms (Sex Room, Desert Island, Sherlocked) with the highest market share in Poland. Nine rooms are independent SBUs because they do not belong to any group in this macro region. It can be assumed that rival escape rooms in this macro region have different strategies, and they compete against each other. 


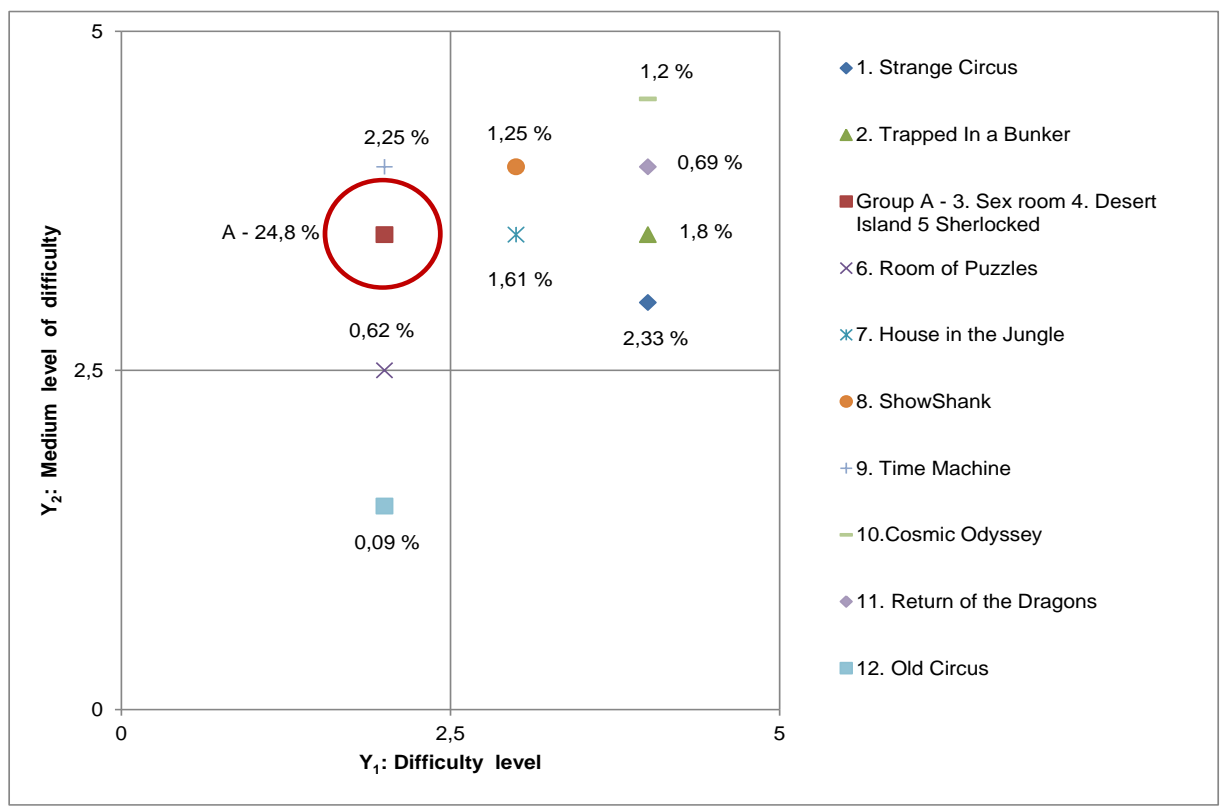

Fig. 7. 1D strategic group map of escape rooms in the Mazovian macro region of Poland

Source: own elaboration based on Lockme.pl

According to the data presented in Figure 8 the analyzed escape rooms in the Northern macro region in Poland are in the convergence field in the evaluation of the difficulty level. On the map there are two strategic groups and seven independent SBUs.

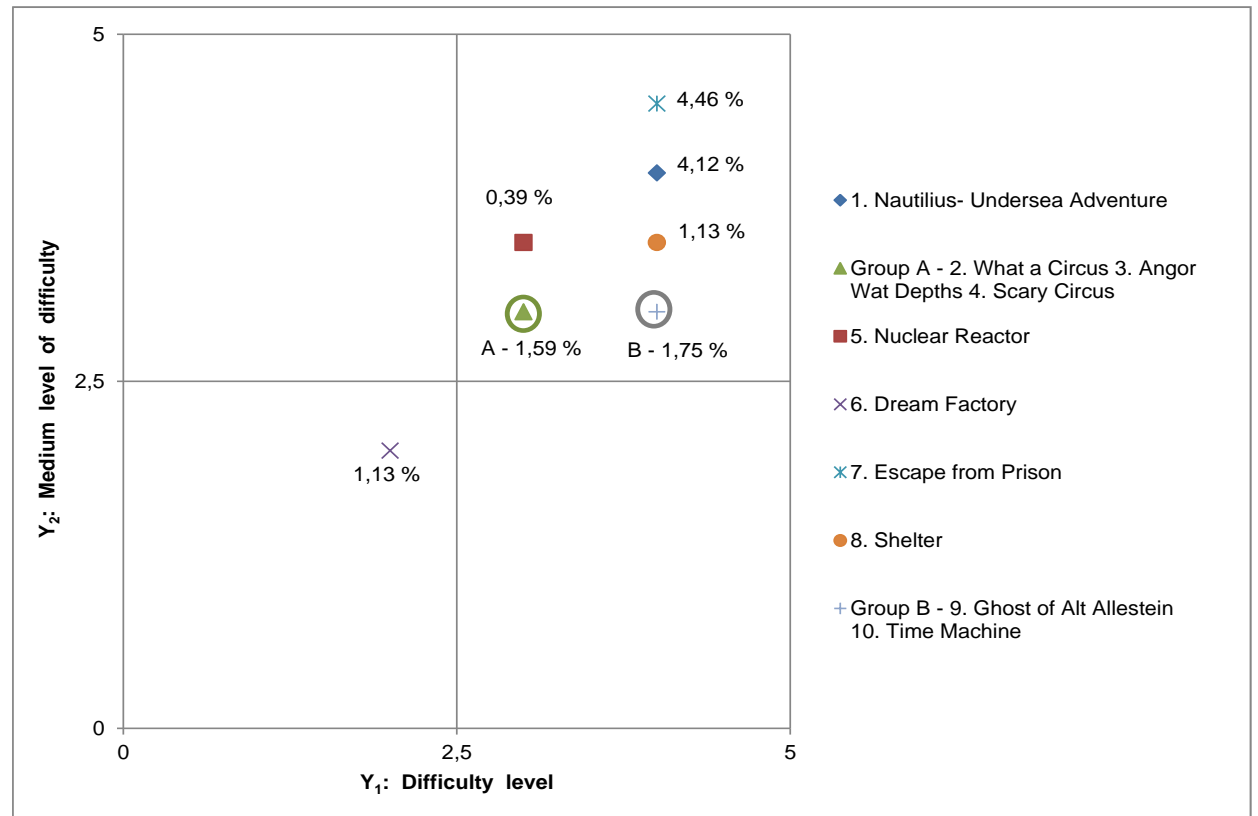

Fig. 8. 1D strategic group map of escape rooms in the Northern macro region of Poland

Source: own elaboration based on Lockme.pl 


\section{ENTREPRENEURSHIP AND SUSTAINABILITY ISSUES}

ISSN 2345-0282 (online) http://jssidoi.org/jesi/

2020 Volume 7 Number 3 (March)

http://doi.org/10.9770/jesi.2020.7.3(14)

Group A, consisting of three rooms (What a Circus, Angor Wat Depths, and Terrible Circus), has a market share of $1.59 \%$. In the opinion of the clients the "Escape from Prison" and "Nautilus-undersea adventure" rooms, each with more than $4 \%$ share, are more interesting. In the convergence field, there are also two rooms which are independent SBUs, with a market share of, respectively, 1.13\% (Shelter) and 0.39\% (Nuclear Reactor). In the convergence field there is also group B, consisting of two rooms (Ghost of Alt Allenstein, Time Machine) with the $1.75 \%$ market share.

A combined market share in the convergence field is $14.57 \%$. On the basis of the strategic group maps it can be concluded that all escape rooms tested in the northern part of the country have a strategy to a greater or lesser extent adequate to the needs and expectations of clients in terms of the difficulty level.

The research presented in part 6 allowed for positive verification of the research hypothesis which assumed that 1D (one-dimensional) strategic group map can have various applications in strategic analysis.

\section{Procedures to be followed in the development of 2D multi-sector strategic group maps and 1D strategic group maps}

For the 2D variant of multi-sector strategic group map a procedure consisting of the following stages is proposed.

a. The selection of variables as differentiation elements in the sector (e.g., for escape room companies in Poland they are: the price of a room, the place of a room in the ranking, its difficulty level).

b. The selection of variables for the criterion of the geographical area in which the analyzed organizations do their business (e.g. for escape room companies in Poland it can be NUTS1 macro-regions).

c. The presentation of variables in tables, along with their levels of evaluations (e.g., 1- low; 2 - average; 3-high), or applying a scale for each variable being evaluated.

d. The assignment of numbers to individual regions of the geographical area (e.g., for escape room companies in Poland 1- the Central macro region; 2- the Southwest macro region; 3- the Mazovian macro region; 4- the Eastern macro region; 5- the Northern macro region; 6-the Northwestern macro region; 7- the Southern macro region).

e. Drawing up various variants of multi-sector 2D strategic group maps applying coordinate axes (X, Y) with selected pairs of variables and the corresponding scale (e.g., for escape room companies in Poland see figures 2-4).

f. Putting values from tables on the $\mathrm{X}, \mathrm{Y}$ axes, with the names or symbols of entities in the analyzed sector.

g. Illustrating the shares of strategic groups consisting of SBUs in the coordinate system with circles of various diameters. The shares are measured as a percentage of the total number of votes of escape rooms clients.

h. Using horizontal and vertical interpretation of the results to evaluate the competitive situation in relation to each variable pair in various sectors extracted geographically.

For the variant 1D strategic group map a procedure consisting of the following stages is proposed:

a. The selection of variables as differentiation strategy elements in the analyzed sector (e.g., for escape room companies in Poland they are: the difficulty level of the room, the average evaluation of difficulty).

b. The presentation of variables in tables, along with their assignment to their respective level on the scale (e.g., $1-5)$.

c. Drawing up various variants of 1D strategic group maps through positioning selected pairs of variables and corresponding levels based on the evaluations of various stakeholder groups of the sector (e.g., for escape room companies in Poland see figures 6-8) on coordinate axes $\left(\mathrm{Y}_{1}, \mathrm{Y}_{2}\right)$.

d. The distribution of values from the tables on $\mathrm{Y}_{1}, \mathrm{Y}_{2}$ axes, with names or symbols of the entities in this sector.

e. Illustrating the shares of strategic groups consisting of SBU in the coordinate system with circles of different diameters. The shares are measured as percentage of the total number of votes of escape room clients in each group. 


\section{ENTREPRENEURSHIP AND SUSTAINABILITY ISSUES}

ISSN 2345-0282 (online) http://jssidoi.org/jesi/

2020 Volume 7 Number 3 (March)

http://doi.org/10.9770/jesi.2020.7.3(14)

f. The interpretation of the results in the context of the evaluation of the situation in the sector extracted geographically according to various stakeholder groups.

\section{Conclusions of the analysis and recommendations}

Partial analysis of the competitive situation in the escape room sector (separated geographically using NUTS 1) with 2D strategic group maps allows the following conclusions:

- in most (86\%) analyzed rooms the minimum prize as differentiation strategy elements is at level 2 (67-133 PLN); in the richest macro regions of Poland: Mazovian, Southwestern and Central, the services of escape rooms are at level 3 of the minimum price (higher than 134 PLN), and in the Eastern and Northern macro regions they are at level 1 of the minimum price (lower than 66 PLN);

- in nearly half (49\%) of analyzed rooms the criterion of differentiation strategy showing the place of the room in the ranking is at level 3; in Eastern, Northern, and Southern macro regions of Poland escape rooms are visited by clients posting their opinions on Lookme.pl and encouraging others to use the services;

- the largest group (41.5\%) are the rooms with difficulty level 3 as a differentiation strategy element (for the intermediate); in all Polish macro regions in principle there are no rooms for the declared levels of 1 and 5 (for those playing for the first time and for proficient players), while rooms for beginners (level 2) are the most popular in the Mazovian macro region, with the most complex puzzles (level 4) preferred by clients in the Northern macro region.

Multi-sector 2D strategic groups maps:

- show the competitive position of a local/regional entity in different geographic locations;

- allows making horizontal analysis and drawing conclusions, comparing the competitive position based on selected levels included for testing criteria/variables in different regions/macro regions/countries;

- allows making vertical analysis and drawing conclusions, comparing the competitive position based on one criterion/variable in one region/macro region/international market;

- can be used to draw conclusions from the analysis, on the one hand, adjusting the strategies of analyzed entity/SBU to the specific situation of competitive advantage in competitive conditions, on the other hand, enabling investors to compare their situation to that in other markets and to take decisions concerning amendments to the strategy or changes in their markets.

Depending on who the analysis is made for all sorts of practical conclusions can be formulated. If the analysis is carried out for owners of escape room businesses, a map presenting current situations across macro regions could be a hint at where to locate the investment. The information presented on the maps allows, for example, deciding in which of the macro regions it would be profitable to set up new divisions (rooms), or what marketing strategies, concerning the price, room type, location, level of difficulty, potential clients should be adopted. From the point of view of the investors, the multi sector 2D strategic group maps can be an indication which macro region would be profitable to allocate the money.

Partial analysis of the competitive situation in the escape room sector (separated geographically with NUTS 1) using 1D strategic group maps allows the conclusion that:

- $\quad$ in two analysed macro regions (the Southern, the Northern) escape room strategies match the difficulty level to clients' expectations, taking into account the total value of the market shares from the convergence fields of stakeholder groups;

- $\quad$ in the Mazovian macro region the divergence level in the evaluation of owners and clients is higher, which means that the strategies for game difficulty are not well matched to the expectations of external stakeholders. 


\section{ENTREPRENEURSHIP AND SUSTAINABILITY ISSUES}

ISSN 2345-0282 (online) http://jssidoi.org/jesi/

2020 Volume 7 Number 3 (March)

http://doi.org/10.9770/jesi.2020.7.3(14)

The result of the studies and of the use of the variant 1D strategic group maps are conclusions and recommendations concerning this variant. The 1D strategic groups maps:

- facilitate analysis of the competitive position of an entity/SBU at any given point in time (statically), presenting a visual description of the competitive position, evolving or existing, in the specified period;

- can be used for the diagnosis and assisting in decision-making processes useful for people working on the development of an entity/SBU, which allows searching for a sequence of short-term competitive advantages;

- are part of a comprehensive evaluation of the competitive position of the sector, allowing a comparison of objective and subjective evaluations of different stakeholder groups;

- facilitate systematizing knowledge about the degree of the implementation of adopted strategies and about general trends in the sector;

- can inspire managers to change strategies of entities/SBU (e.g., as a result of the evaluation of the competitive situation on the 1D map not satisfying the stakeholders, a map can be a stimulus to change the strategy, as well as to look for the causes of the situation);

- allow individuals responsible for the development of escape room companies to search for answers to questions about the causes of the diagnosed changes and cause-and-effect relationships arising from the situation identified on the map;

- allow determining courses of action for the future with regard to specific criteria;

- compare evaluations of different stakeholder groups, with decision-making bodies being able to correct current activities of the entity;

- can provide a visual representation of individual criteria/variables from the point of view of various stakeholder groups, for example, presenting the evaluation of the difficulty level of individual rooms, the time needed to solve the puzzles, or a need to make the game easier or more difficult.

In this article an analysis of the situation in the sector was carried out only in statistical terms. However, according to the authors, it is possible to use dynamic approach also in relation to the 1D maps (Multan, WójcikAugustyniak, 2017). The application of dynamic analysis may facilitate determination whether the right decisions have been taken.

On the basis of the study on escape rooms sector in Poland it can be concluded that the purpose of the article has been achieved. Scientific problem has been solved and the hypothesis '2D (two-dimensional) and 1D (onedimensional) strategic group maps can have various applications in strategic analysis' has been verified positively.

The main contribution of this article to management sciences is:

- The novelty of using variants of 2D and 1D strategic group maps. Multi-sector strategic group maps (2D) enable comparisons between NUTS. Until now, in management sciences researchers have focused on comparing and presenting companies /organizations in the context of their type of activity, without focusing on comparisons and presentations of the geographical context. Variant 1D allows confronting the opinions of various stakeholder groups.

- The proposed new variants of strategic group maps are tools that support the right strategic decisions of managers of modern organizations, taking into account feedback from stakeholders in their strategies.

In addition, the authors undertook theoretical reflection on strategic group maps, and variants of two-dimensional and one-dimensional group maps were created based on the analysis of the escape rooms sector, which has not been studied in this scope so far. 


\section{ENTREPRENEURSHIP AND SUSTAINABILITY ISSUES}

ISSN 2345-0282 (online) http://jssidoi.org/jesi/

2020 Volume 7 Number 3 (March)

http://doi.org/10.9770/jesi.2020.7.3(14)

\section{References}

Area and Population in the Territorial Profile in 2017. Statistical Information and Elaborations 2017. Warszawa: GUS (Central Statistical Office). Retrieved August 05, 2018, from https://stat.gov.pl/obszary-tematyczne/ludnosc/ludnosc/powierzchnia-i-ludnosc-w-przekrojuterytorialnym-w-2017-r-, 7,14.html

Bence, G. (2016). ParaPark, from tökéletes élmény egy romkocsma pincéjében. velvet.hu. Retrieved July 18, 2018, from https://velvet.hu/trend/2011/09/09/parapark_tokeletes_elmeny_egy_romkocsma_pincejeben/

By the numbers: UK vs the rest of the world. 2017. exitgames.co.uk. Retrieved July 15, 2018, from http://exitgames.co.uk/blog/2017/09/14/by-the-numbers-uk-vs-the-rest-of-the-world/

Cheng, E. (2014). Real-life 'escape rooms' are new US gaming trend. CNBC. Retrieved August 18, 2018, from https://www.cnbc.com/2014/06/21/real-life-escape-rooms-are-new-us-gaming-trend.html

Classification of Territorial Units for Statistics (NUTS). Warszawa: GUS (Central Statistical Office). Retrieved August 05, 2018, from http://stat.gov.pl/en/regional-statistics/classification-of-territorial-units/classification-of-territorial-units-for-statistics-nuts/

Commission Regulation (EU) 2016/2066 of 21 November 2016 amending the annexes to Regulation (EC) No 1059/2003 of the European Parliament and of the Council on the establishment of a common classification of territorial units for statistics (NUTS) (OJ L 322, 29.11.2016: 1-61).

Cool, K., Dierickx, I. (1993). Rivalry, Strategic Groups and Firm Profitability. Strategic Management Journal, $14,47-59$.

Escape room, room escape, escape game, pokoje zagadek czyli nowy wymiar w branży rozrywkowej. (Escape room, room escape, escape game, puzzle rooms - a new dimension in the entertainment industry) (2016). Rzeczpospolita. Retrieved August 05, 2018, from https://www.rp.pl/160539820-Escape-room-room-escape-escape-game-pokoje-zagadek-czyli-nowy-wymiar-w-branzy-rozrywkowej.html

Figurska, I. (2014). Sustainable entrepreneurship: localization, acquiring and use of knowledge sources in competitive organization. Entrepreneurship and Sustainability Issues 1(4): 210-222. DOI: http://dx.doi.org/10.9770/jesi.2014.1.4(3)

French, S., Shaw, J.M. (2015). The unbelievably lucrative business of escape rooms. MarketWatch. Retrieved August 10, 2018, from https://www.marketwatch.com/story/the-weird-new-world-of-escape-room-businesses-2015-07-20

Gierszewska, G., Romanowska, M. (2017). Analiza strategiczna przedsiębiorstwa. (Strategic analysis of the enterprise). Warszawa: PWE.

Hunt, M.S. (1972). Competition in the Major Home Appliance Industry. 1960-1970. Unpublished Ph.D. dissertation, Harvard University.

Jeannet, J.-P., Schreuder, H. (2015). From Coal to Biotech: The Transformation of DSM with Business School Support. Heidelberg: Springer. ISBN 978-3-662-46298-0.

Kowalik, A. (2015). Ucieczka do pieniędzy. (Escape to the money). Forbes. Retrieved August 10, 2018, from https://www.forbes.pl/pierwszy-milion/escape-roomy-podbijaja-polske/661rybg

Koza, I. (2018). An Endogenous Potential of Poland and its Regions. Zeszyty Naukowe Uniwersytetu Przyrodniczo-Humanistycznego w Siedlcach, Seria: Administracja i Zarzadzanie, Nr 117 (44), 55-63. ISSN 2082-5501

Lockme.pl. Retrieved August 08, 2018, from https://lockme.pl/ranking-escape-room/

Marinho, N. (2012). The Real Escape Game in Singapore. Recognition pattern. Retrieved August 10, 2018, from https://web.archive.org/web/20120724092041/http://recognitionpattern.com/2012/01/31/the-real-escape-game-in-singapore/ 


\section{ENTREPRENEURSHIP AND SUSTAINABILITY ISSUES}

ISSN 2345-0282 (online) http://jssidoi.org/jesi/

2020 Volume 7 Number 3 (March)

http://doi.org/10.9770/jesi.2020.7.3(14)

McGee, J., Thomas, H. (1986). Strategic Groups: Theory, Research and Taxonomy. Strategic Management Journal, 7(2), 141-160.

Multan, E., Wójcik-Augustyniak, M. (2016). Research methodology of the entrepreneurship and innovativeness of higher education institutions. Edukacja Ekonomistów i Menedżerów. Problemy. Innowacje. Projekty, 42, 83-98. https://eeim.kwartalnik.com.pl/resources/html/article/details?id=140015. DOI: $\underline{\text { https://doi.org/10.5604/01.3001.0009.5493. }}$.

Multan, E., Wójcik-Augustyniak, M. (2017). Mapa grup strategicznych 3D - idea, procedura i zastosowanie praktyczne. (The strategic groups maps 3d-idea, procedure and practical application). Organization and Management, 4(178), 67-84, http://kolegia.sgh.waw.pl/pl/KZiF/czasopisma/oik/numery/Documents/2017_NR_4_(178).pdf

Porter, M.E. (1994). Strategia konkurencji. Metody analizy sektorów i konkurentów. (Competitive Strategy: Techniques for Analyzing Industries and Competitors). Warszawa: Polish edition by PWE.

Principles for creation and development of NUTS units. Warszawa: GUS (Central Statistical Office). Retrieved May 15, 2018, from http://stat.gov.pl/en/regional-statistics/classification-of-territorial-units/classification-of-territorial-units-for-statistics-nuts/principles-forcreation-and-development-of-nuts-units/

Raspopina, S. (2015). Great escapes: the strange rise of live-action quest games in Russia. The Guardian. Retrieved August 10, 2018, from https://www.theguardian.com/world/2015/jul/23/russia-escape-games-quest-moscow-stpetersburg

Regional Innovation Scoreboard (2017), European Commission, Document date: 20/06/2017: https://ec.europa.eu/docsroom/documents/24181

Regulation (EC) No 1059/2003 of the European Parliament and of the Council of 26 May 2003 on the establishment of a common classification of territorial units for statistics (NUTS) (OJ L 154, 21.6.2003, p. 1-41).

Regulation (EC) No 1888/2005 of the European Parliament and of the Council of 26 October 2005 amending Regulation (EC) No $1059 / 2003$ on the establishment of a common classification of territorial units for statistics (NUTS) by reason of the accession of the Czech Republic, Estonia, Cyprus, Latvia, Lithuania, Hungary, Malta, Poland, Slovenia and Slovakia to the European Union (OJ L 309, 25.11.2005, p. 1-8).

The NUTS classification in Poland. Warszawa: GUS, Retrieved August 08, 2018, from http://stat.gov.pl/en/regionalstatistics/classification-of-territorial-units/classification-of-territorial-units-for-statistics-nuts/the-nuts-classification-in-poland/

Waterhouse, J. 2015. For \$28, this Alpharetta business will lock you inside a room. MyAJC. https://www.myajc.com/entertainment/attractions/for-this-alpharetta-business-will-lock-you-inside-room/zKjBaCJt2KyLy8I9ByycBJ/

Wójcik-Augustyniak, M., Multan, E. (2017). Klasyczna mapa grup strategicznych (2D) jako podstawa oceny sytuacji konkurencyjnej w sektorze publicznych szkół wyższych w Polsce w obszarze innowacyjności i przedsiębiorczości (Classic Strategic Groups Maps (2D) as the Basis for Assessing the Competitive Situation in the Sector of Public Universities in Poland in the Area of Innovativeness and Entrepreneurship). e-mentor, 1(68), 20-28. $\quad$ http://www.e-mentor.edu.pl/artykul/index/numer/68/id/1283. DOI: https://doi.org/10.15219/em68.1283. 


\section{ENTREPRENEURSHIP AND SUSTAINABILITY ISSUES}

ISSN 2345-0282 (online) http://jssidoi.org/jesi/

2020 Volume 7 Number 3 (March)

http://doi.org/10.9770/jesi.2020.7.3(14)

Marzena WÓJCIK-AUGUSTYNIAK, habilitated $\mathrm{PhD}$ is the Associate Professor at Siedlce University of Natural Sciences and Humanities, Poland, a Chief Editor of "The Scientific Papers of the Siedlce University of Natural Sciences and Humanities, Series: Administration and Management", the Project Team Leader of the Siedlce University at the Project "Certified Digital Accessibility Training" within ERASMUS+ Programme, Member of the Organizational Committee of the International Conference MANAGEMENT.

Research interests: strategic management, including strategic analysis; higher education institutions, value innovation.

ORCID ID: $\underline{\text { https://orcid.org/0000-0001-5096-2863 }}$

Ewa MULTAN, PhD, is the Assistant Professor at Siedlce University of Natural Sciences and Humanities, Poland, project manager of "Competences of tomorrow's employees ine the business services sector" project of the National Research and Development Center cofinanced by the European Union. Leader of "Liga Menedżerów Biznesu" (Business Managers League), a nationwide competition; leader of "Synergia nauki i biznesu" (Business and Science Synergy) conference; Research interests: strategic management including strategic analysis, network analysis, academic entrepreneurship.

ORCID ID: $\underline{\text { https://orcid.org/0000-0003-4855-0645 }}$

Register for an ORCID ID:

https://orcid.org/register

Copyright (C) 2020 by author(s) and VsI Entrepreneurship and Sustainability Center

This work is licensed under the Creative Commons Attribution International License (CC BY).

http://creativecommons.org/licenses/by/4.0/

C) (i) Open Access 